\title{
Uji Bakteriologis Es Batu Rumah Tangga yang digunakan Penjual Minuman di Pasar Lubuk Buaya Kota Padang
}

\author{
Basri Hadi, Elizabeth Bahar, Rima Semiarti
}

\begin{abstract}
Abstrak
Es batu digunakan untuk minuman dan terbuat dari air. Nilai sanitasi dan kehegienisan yang baik suatu minuman/makanan adalah tidak ditemukan adanya kuman E. coli sebagai parameter karena E. coli merupakan flora normal usus yang keluar bersama tinja dimana sebagai sumber infeksi terhadap makanan dan minuman. Dalam rangka meningkatkan derajat kesehatan masyarakat perlu dilaksanakan berbagai upaya kesehatan termasuk pengawasan kualitas makanan dan minuman. Telah dilakukan penelitian deskriptif dengan menggunakan metoda indeks MPN (Most Propable Number) di bagian Mikrobiologi Fakultas Kedokteran Universitas Andalas. Penelitian ini bertujuan untuk menilai kualitas bakteriologis es batu Rumah Tangga yang digunakan penjual minuman di pasar Lubuk Buaya kota Padang. Hasil penelitian menunjukkan bahwa 88,9\% sampel es batu Rumah Tangga yang digunakan penjual minuman di pasar Lubuk Buaya kota Padang belum memenuhi syarat kesehatan, dengan angka MPN yang bervariasi. Dari hasil penelitian ini dapat disimpulkan bahwa sanitasi dan higienis es batu Rumah Tangga yang digunakan penjual minuman di pasar Lubuk Buaya kota Padang terkontaminasi bakteri koliform.
\end{abstract}

Kata kunci: Uji Bakteriologis, Es Batu, MPN

\begin{abstract}
Ice cube is widely use for drinks and beverages, it made from water.Good sanitation and hygienic value of a food/drink is determined by the founding of the E. coli germ as a parameter, since the $E$. coli is a normal flora of the intestine that is secreted together with feces, which is an infection-resulting source on food and drink. In order to improve the health of public, many efforts need to be done, including the monitoring of foods and drinks quality. A descriptive study has been done with index method of MPN (Most Probable Number) in Microbiology section of Medical Faculty Andalas University. This study is aimed to determine the bacteriological qualiti of Ice cube were use by seller drinks at the pasar Lubuk Buaya kota Padang. Result of the study shows that $88,9 \%$ sampel of ice cube were use by seller drinks at the pasar Lubuk Buaya kota Padang has not fulfilled the medical conditions yet, with the various number of MPN. From the result, it is concluded that the sanitation and hygienic of ice cube were use by seller drinks at the pasar Lubuk Buaya kota Padang is contaminated by coliform bactery.
\end{abstract}

Keywords:Bacteriological test, ice cube, MPN

Affiliasi penulis : Fakultas Kedokteran Universitas Andalas,

Korespondensi : Basri Hadi Nasution, email :

basrihadinasution@gmail.com, Telp: 082382311113

\section{PENDAHULUAN}

Es batu merupakan produk pelengkap yang sering disajikan bersama minuman dingin dan dianggap aman untuk dikonsumsi.Dalam masyarakat, es batu dikenal sebagai air yang dibekukan.Pembekuan ini terjadi bila air didinginkan di bawah 0 으. Air yang digunakan dalam pembuatan es batu haruslah air yang higienis dan memenuhi standar sanitasi. Sampai saat ini, belum ada peraturan pemberian izin atau rekomendasi kelayakan usaha es batu yang baku ditinjau dari segi higienis dan sanitasi, dikarenakan usaha es batu masih dalam skala kecil dan merupakan usaha rumah tangga, sehingga higienis dan sanitasinya masih diragukan. ${ }^{1}$

Hasil uji kualitas bakteriologis air yang dilakukan oleh dinas kesehatan kota Padang, wilayah Lubuk Buayaberada pada presentase 5 terbawah, dengan nilai $54,7 \%$ sedangkan hasil uji terbaik $62,0 \%$. Kualitas air yang rendah disebabkan oleh buruknya sanitasi lingkungan. ${ }^{2}$

Keberadaanbakteri pencemar menyebabkan rendahnya kualitas es batu yang mungkin berasal dari berbagai hal seperti: bahan baku (air) dan alat-alat yang digunakandalam proses pembuatan es batu. ${ }^{1}$
Bakteri golongan Enterobacteriaceae atau bakteri enteric merupakan bakteri yang sering mengkontaminasi air.Famili ini mencakup banyak genus diantaranya Escheriaceae, Shigela, Salmonella, Enterobacter, Klebsiella, Serrtia dan Proteus sebagai bakteri-bakteri penyebab infeksi saluran cerna. Escheria coli (E.coli) pada air minum dapat dijadikan parameter atau indikator tingkat pencemaran air secara bakteriologis, karena Escheria coli merupakan flora normal usus yang ikut bersama tinja.

Air minum tidak boleh mengandung bakteribakteri penyakit (pathogen), uji kualitas air dapat ditentukan berdasarkan indeks MPN, dimana Escheria coli sebagai indikator dari pemeriksaan air dan makanan yang berarti tidak boleh melewati batas yang ditentukan yaitu $0 / 100 \mathrm{ml}^{\text {air. }}{ }^{3}$

Air akan menjadi salah satu penyebab terjadinya penyakit diare dikarenakan air telah terkontaminasi oleh bakteri, dapat dilihat dari kasus diare sebanyak 1115 kasus di Puskesmas Lubuk Buaya, dengan jumlah kasus diare kota Padang 13.130 kasus, dengan kesimpulan daerah Lubuk Buaya merupakan daerah terbanyak kasus diare. ${ }^{2}$

Penyakit diare sampai saat ini masih termasuk dalam urutan 10 penyakit terbanyak di kota Padang. Dalam rangka mengatasi masalah penyakit diare di kota Padang dan meningkatkan derajat kesehatan masyarakat perlu dilaksanakan berbagai upaya 
kesehatan, termasuk pengawasan kualiatas air minum yang dikonsumsi oleh masyarakat. ${ }^{2}$

\section{TINJAUAN PUSTAKA}

Perbedaan Es Batu yang Terbuat dari Air Matang dan Mentah

Es dari air mentah berwarna putih karena masih banyak gas yang terperangkap di dalamnya.Biasanya, es yang dibuat dari air mentah adalah es Balok.Es ini jelas-jelas tidak baik dikonsumsi, terlebih lagi jika airnya diambil dari air sungai yang tercemar. ${ }^{1}$

Es dari air matang akan terlihat bening karena gas di dalam air terlepaskan ketika proses perebusan. Biasanya, es seperti ini disebut es kristal. Sekarang, menurut pengamatan TS, es kristal sudah banyak dipakai, TS menyebut nya es batu bolong, soalnya berbentuk pipa, bolong di tengah. ${ }^{1}$

\section{Penyebaran Penyakit Melalui Air}

Infeksi asal air,sebagaimana halnya penyakit asal makanan disebabkan oleh mikroorganisme yang memasuki dan meninggalkan inang lewat rute mulut usus.Infeksi semacam itu disebut juga infeksi enterik karena ususlah yang terinfeksi.Penyakit asal air terjadi karena meminum air tercemar.Penyakit yang disebabkan oleh pencemaran air ini disebut waterborne disease dan sering ditemukan pada penyakit tifus, kolera dan disentri.Sebenarnya sumber infeksi itu bukanlah airnya melainkan tinja yang berasal dari manusia atau hewan yang telah mencemari air tersebut.Tinja tersebut mengandung patogen-patogen enterik bila berasal dari orang sakit atau carrier. ${ }^{4}$ Bagaimanapun juga, dengan cara penularan lewat air itulah wabah infeksi enterik yang dapat menjangkiti banyak orang.

\section{Pengertian Metode Indeks MPN}

Untuk mendeteksi dan menghitung jumlah coliform dalam air ada 3 metoda yang dapat digunakan yaitu: Standard plate count (SPC), the multiple-tube method (disebut juga metoda "Most Probable Number, MPN), dan the membranefiltration. ${ }^{5}$

Prinsip tes pertama dan ketiga adalah sifat bakteri yang berkembang baik dalam waktu 24 sampai 72 jam pada suhu tertentu (dalam incubator) dan dalam suasana yang cocok yaitu sebuah media yang terdiri dari agar-agar yang mengandung beberapa jenis zat kimia yang merupakan gizi bagi jenis bakteri tertentu serta dapat mengatur nilai $\mathrm{pH}$.

Prinsip tes kedua (metoda MPN) adalah sama dengan prinsip tes pertama, hanya bakteri tidak berkembangbiak pada media (agar-agar) tapi tersuspensi dalam kaldu (borth media) yang mengandung gizi untuk pertumbuhannya. Bakteribakteri tersebut dapat dideteksi karena jenis bakteri tersebut mampu meragikan (fermentasi) salah satu unsure zat gizi seperti laktosa yang akibat proses peragian tersebut terbentuklah gas, gelembunggelembung gas ini menunjukkan adanya bakteri tersebut. $^{6}$

Pemeriksaan mikrobiologis air sangat diperlukan untuk mencegah timbulnya pencemaran terhadap air yang dikonsumsi oleh manusia. Salah satu metode yang sering digunakan yaitu Most Propable Number Method (MPN). MPN merupakan suatu metode tabung fermentasi yang dapat digunakan untuk mendeteksi adanya bakteri pada air. ${ }^{7}$

\section{Jenis Penelitian}

Penelitian yang dilakukan bersifat deskriptif yaitu memberikan gambaran mengenai kualitas bakteriologis es batu rumah tangga yang digunakan penjual minuman di pasar Lubuk Buaya kota Padang.

\section{Populasi dan Sampel Penelitian}

Populasi adalah semua produsen es batu rumah tangga yang digunakan penjual minuman di pasar Lubuk Buaya kota Padang yang berjumlah 9.

Sampel pada penelitian ini adalah seluruh dari populasi dijadikan sampel berjumlah sembilan. Sampel berupa es batu rumah tangga yang memenuhi kriteria yaitu dikemas dalam kemasan plastik, lalu diikat dengan karet, volume yang sama \pm 1000 $\mathrm{ml} / \mathrm{sampel}$.

\section{METODA DAN CARA KERJA}

Pada penelitian ini dilakukan uji coliform menggunakan tabung seri ganda 5-1-1 (5 double lactose broth, 1-1 single lactose broth) sebagaimana yang terdapat dalam petunjuk pemeriksaan bakteriologis air. Pada uji ini digunakan ragam $5 \times 10$ $\mathrm{ml}, 1 \times 1 \mathrm{ml}, 1 \times 0,1 \mathrm{ml}$ karena mengambil spesimen yang sudah diolah atau angka kumannya diperkirakan rendah.

Menyiapkan media steril yaitu untuk media Lactose Broth double strength dan single strength dan Brilliant Green Lactose Broth, diisi media $10 \mathrm{ml}$ tiap tabung lengkap dengan tabung durham posisi terbalik. Pemeriksaan coliform meliputi tahap:

\section{Uji Penduga (Presumtive test)}

Sederetan tabung berisi media LB standar 5 1-1 masing-masing diisi sampel $10 \mathrm{ml}, 1 \mathrm{ml}, 0,1 \mathrm{ml}$ dengan menggunakan Spuit Disposible yang telah steril. Pengisian dilakukan seaseptis mungkin. Semua tabung dimasukkan dalam inkubator pada suhu $37^{\circ} \mathrm{C}$ dan ditunggu $1 \times 24$ jam, $2 \times 24$ jam, dan $3 \times 24$ jam.Hasil fermentasi positif jika terjadi fermentasi laktosa oleh kuman coli sampel, sehingga terbentuk gas yang dapat dilihat berupa rongga kosong pada bagian atas tabung Durham terbalik yang ada dalam media LB.

\section{Uji Penegas (Confirmative test)}

Tabung yang positif pada presumptive test dilanjutkan dengan uji penegas.Kemudian masingmasing sampel yang positif menunjukkan gas, ditanam pada media BGLB dengan standar tabung 5-1-1. Inokulasi dari biakan positif pada media LB ke media BGLB dilakukan dengan menggunakan ose dan diinkubasi dalam inkubator pada suhu $37^{\circ} \mathrm{C}$ dan ditunggu $1 \times 24$ jam, $2 \times 24$ jam, dan $3 \times 24$ jam. Jika terbentuk gas pada beberapa tabung media BGLB, maka dapat disesuaikan dengan tabel indeks MPN 51-1 (lampiran) sesuai dengan angka jumlah tabung yang positif. ${ }^{3}$

\section{Pengolahan dan Analisis Data}

Data yang didapat diolah secara manual dalam bentuk tabel.

\section{Hasil Pemeriksaan Es Batu Rumah Tangga}

Penelitian ini dilakukan dari bulan Oktober 2012 sampai Januari2013 dengan mengambil sampel es batu rumah tangga yang digunakan penjual minuman di pasar Lubuk Buaya kota Padang dari seluruh populasi yang ada. Data didapatkan dari hasil 
observasi, wawancara, dan hasil penelitian di Laboratorium Mikrobiologi Fakultas Kedokteran Universitas Andalas Padang.

\section{Tes Penduga (Presumptive)}

Tes presumtif dilakukan dengan menginokulasikan sampel ke dalam media Lactose broth (LB) tabung seri ganda 5-1-1 (5 double lactose broth, 1-1 single lactose broth). Sederetan tabung berisi media LB standar 5-1-1 masing-masing diisi sampel $10 \mathrm{ml}, 1 \mathrm{ml}, 0,1 \mathrm{ml}$ dengan menggunakan Spuit Disposible yang telah steril. Total tabung reaksi yang digunakan sebanyak 63 tabung. Pada tabel 1 menunjukkan hasil pemeriksaan tes penduga pada 9 sampel es batu rumah tangga. Hasil bernilai positif bila terdapat gelembung udara di dalam tabung Durham seperti gambar 1. Hasil yang didapatkan adalah sebagai berikut:

Tabel 1. Hasil tes presumtif

\begin{tabular}{|c|c|c|c|c|c|c|c|}
\hline No & \multicolumn{5}{|c|}{ Sampel 10 ml } & $\begin{array}{c}\text { Sampel 1 } \\
\text { ml }\end{array}$ & $\begin{array}{c}\text { Sampel } \\
\mathbf{0 , 1} \text { ml }\end{array}$ \\
\hline 1 & + & + & + & + & + & + & - \\
\hline 2 & + & + & + & + & + & + & - \\
\hline 3 & + & + & + & - & - & - & - \\
\hline 4 & + & + & + & + & + & + & + \\
\hline 5 & + & + & + & + & + & + & - \\
\hline 6 & + & + & + & + & + & + & + \\
\hline 7 & + & + & + & + & + & + & + \\
\hline 8 & - & - & - & - & - & - & - \\
\hline 9 & + & + & + & + & + & + & - \\
\hline
\end{tabular}

Keterangan: + :Terdapat gelembung udara di dalam tabung Durham

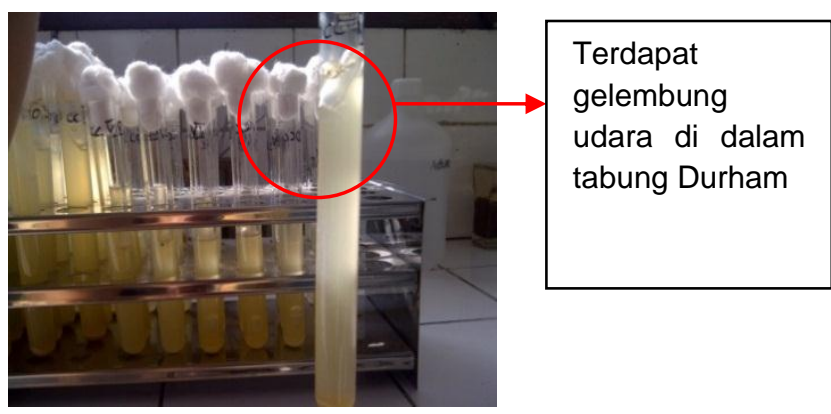

Gambar 1. Hasil positif pada tes presumtif

Pada tabel, satu orang penjual es batu rumah tangga menggunakan air PAM yang sudah dididihkan untuk pembuatan es batu, yaitu sampel nomor 8.Pada tes presumtif sampel nomor8tidak ada terdapat gelembung udara di dalam tabung durham. Delapan orang penjual lainnya menggunakan air sumur milik sendiri untuk pembuatan es batu rumah tangga tersebut.Semua penjual memasak air terlebih dahulu sebelum air tersebut dibungkus kedalam plastik.Namun mereka dalam memasak air tidak sampai mendidih, sehingga bakteri yang ada didalam air tersebut tidak sampai mati. Pada tes presumtif delapansampel terdapat gelembung udara di dalam tabung durham. Seluruh sampel yang bernilai positif pada tes presumtif dilanjutkan ke pemeriksaan konfirmatif.

\section{Tes Konfirmatif (Confirmative)}

Pemeriksaan presumtif dilanjutkan dengan pemeriksaan konfirmatif.Pemeriksaan konfirmatif menginokulasikan sampel ke dalam media Brilliant Green Lactose Broth (BGLB) dengan menggunakan jarum ose sedang. Sampel yang digunakan adalah seluruh hasil positif yang ada pada tes presumtif, dan diinkubasikan selama24 - 48 jam. Hasil bernilai positif jika terdapat gelembung udara di dalam tabung Durham, seperti pada gambar2. Hasil tes konfirmatif yang diperoleh tertera pada tabel 2.

Tabel 2. Hasil tes konfirmatif

\begin{tabular}{|c|c|c|c|c|c|c|c|c|}
\hline No & \multicolumn{5}{|c|}{ Sampel 10 ml } & $\begin{array}{c}\text { Sampel 1 } \\
\text { ml }\end{array}$ & $\begin{array}{c}\text { Sampel } \\
\mathbf{0 , 1} \text { ml }\end{array}$ & $\begin{array}{c}\text { Nilai } \\
\text { Indeks } \\
\text { MPN }\end{array}$ \\
\hline 1 & + & + & + & + & + & + & - & 265 \\
\hline 2 & + & + & + & + & + & + & - & 265 \\
\hline 3 & + & + & + & - & - & - & - & 9 \\
\hline 4 & + & + & + & + & + & + & + & $>979$ \\
\hline 5 & + & + & + & + & + & + & - & 265 \\
\hline 6 & + & + & + & + & + & + & + & $>979$ \\
\hline 7 & + & + & + & + & + & + & + & $>979$ \\
\hline 8 & - & - & - & - & - & - & - & 0 \\
\hline 9 & + & + & + & + & + & + & - & 265 \\
\hline
\end{tabular}

Keterangan :

+ :Terdapat gelembung udara di dalam tabung Durham

--: Tidak terdapat gelembung udara di dalam tabung Durham

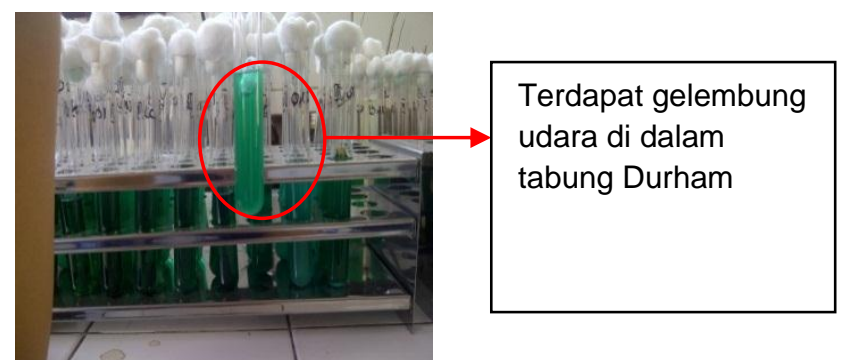

Gambar 2. Hasil positif pada tes konfirmatif

Pada tabel didapatkan semua sampel es batu rumah tangga yang positif pada tes penduga, juga positif pada tes konfirmatif. Hasil positif pada tes konfirmatif menunjukkan terdapat produksi gas yang berarti ada pertumbuhan koloni bakteri Coliform pada medium Brilliant Green Lactose Broth (BGLB).Hasil tes konfirmatif dimasukkan kedalam tabel Most Probable Number (MPN) untuk mencari nilai indeks MPN. Hasil dari nilai indeks MPN adalah jumlah total bakteri Coliform yang ada di dalam $100 \mathrm{ml}$ sampel es batu rumah tangga. Nilai indeks MPN dari yang paling rendah sampai yang tertinggi pada sampel es batu rumah tangga berturut-turut adalah sampel nomor 8 $(0 / 100 \mathrm{ml})$, sampel nomor $3(9 / 100 \mathrm{ml})$, sampel nomor 1, 2, 5, $9(265 / 100 \mathrm{ml})$ dan sampel nomor 4, 6, 7 (> $979 / 100 \mathrm{ml}$ )

\section{KESIMPULAN}

1. Delapan sampel es batu rumah tangga memiliki nilai indeks MPN sekitar 9 sampai > 979 / 100 ml sampel.

2. Satu sampel es batu rumah tangga memiliki nilai indeks MPN 0 / $100 \mathrm{ml}$ sampel.

3. Delapan sampel es batu rumah tangga belum memenuhi syarat kesehatan untuk konsumsi.

\section{Saran}

Untuk pembuatan es batu, masyarakat seharusnya menggunakan air yang sudah dididihkan dan personal higienis yang saniter.Pemeriksaan bakteriologis secara berkala oleh Dinas Kesehatan khususnya Dinas Kesehatan Lingkungan terhadap es batu rumah tangga yang digunakan penjual minuman. Memperhatikan kelayakan dan sehat 
konsumsi dari es batu rumah tangga yang digunakan penjual minuman dari parameter lain sesuai Peraturan Menteri Kesehatan No. 907 tahun 2002.

\section{DAFTAR PUSTAKA}

1. Michael JP Jr. Dasar-dasar mikrobiologi. Jakarta: Universitas Indonesia; 1988.

2. Dinas kesehatan kota Padang. Laporan tahunan tahun 2010. Edisi 2011.

3. Soemarno. Isolasi dan identifikasi bakteri klinik. Akademi Analis Kesehatan Yogyakarta: Departemen Kesehatan Republik Indonesia; 1998.

4. Departemen Kesehatan RI. Keputusan menteri kesehatan RI Nomor 907/Menkes/SK/VII/2002 tentang syaratsyarat dan pengawasan kualitas air minum. 2002.
5. Rahmawati AA, Azizah Perbedaan kadar BOD, COD, TSS, dan MPN coliform pada air limbah, sebelum dan sesudah pengolahan di RSUD Nganjuk. Jurnal Kesehatan Lingkungan; 2005. Tersedia dari: URL: HYPERLINK http://www. MPN Coliform jurnalKesehatanBlogspot.com/index/7035/pe ngolahan-air/lingkungan/2005.html

6. Krisna. Ada coliform di water tap ITB. 2005. Tersedia dari: URL: HYPERLINK http://www. Processing.art.itb.ac.id

7. Widiyanti NLP, Ristiati NP. Analisis kualitatif bakteri koliform pada depo air minum isi ulang di Kota Singaraja Bali. 2004. Tersedia dari: URL: HYPERLINK http://www.koliform kualitasairBlogspot.com/2004/07/air-kualitas coliform-bakteri.html 